\title{
Citizens of the Teaching Commons: The Rise of SoTL Among US Professors of the Year, 1981-2015
}

\section{ABSTRACT}

From 1981 to 2015, the US Professors of the Year program recognized 101 college and university teachers as national winners in its annual competition for faculty who demonstrated "extraordinary dedication to undergraduate teaching." Their dossiers provide a window onto the leading edge of teaching and educational leadership over a critical thirty-five years when innovative faculty nationwide sought to engage a more diverse set of students, enliven the teaching repertoires of their fields, develop new media for instruction, and encourage more active learning in their classrooms and beyond. But that is not all. As the pace of pedagogical change picked up, so too did the level of engagement with colleagues both on and beyond campus on educational issues. The roster of national winners has always included authors of textbooks and other materials, but as time went on, a growing number were also making their approaches to pedagogical problems public through workshops, conference presentations, and publications. Increasingly engaged in the scholarship of teaching and learning, the US Professors of the Year reflect the emergence of a new view of the nature and source of teaching expertise and of what it means to be a "citizen" of the teaching commons.

\section{KEYWORDS}

teaching commons, pedagogical innovation, pedagogical change, scholarship of teaching and learning, national teaching award competitions

\section{INTRODUCTION}

From 1981 to 2015, the US Professors of the Year program recognized 101 college and university teachers as national winners in its annual competition for faculty who demonstrated "extraordinary dedication to undergraduate teaching." "The nomination materials for these faculty provide a unique window on the leading edge of teaching and educational leadership over a critical 35 years, when teaching in higher education was transformed by changing student demographics, new technologies, and new knowledge about how people learn. The national winners of the US Professors of the Year competition reflect the efforts of innovative faculty nationwide to engage and support a more diverse set of students, enliven the standard teaching repertoires of their fields, develop the possibilities of new media for instruction, and encourage more active learning in their classrooms and beyond.

But that is not all. As the pace of pedagogical change picked up, so too did the level of engagement among colleagues on educational issues. As faculty members shared their pedagogical insights and innovations, the teaching commons - that notional space where exchange about teaching and learning occurs (Huber \& Hutchings, 2005) — grew and became better connected as well. Indeed, the dossiers of the US Professors of the Year suggest that what it means to be a "citizen" of the 
commons - one who contributes to and makes use of its resources-also changed as new ideas about what counts as useful knowledge about teaching and learning emerged and took hold. The national winners have always included faculty who excelled as leaders in critical campus conversations, and it has always included authors of textbooks and other materials for use by teachers and students. But as time went on, a growing number were engaging campus colleagues in professional development around new pedagogical practices and reaching out to colleagues beyond campus through workshops, conference presentations, and publications. They were also increasingly engaged in the kinds of classroom inquiry and improvement known as the scholarship of teaching and learning (SoTL) and other kinds of discipline-based education research.

To be sure, the US Professors of the Year are not representative of all college and university instructors in US colleges and universities. They are, by definition, an exceptional group and do not reflect the growing number of faculty in contingent and other non-tenure-track positions over these same years. ${ }^{2}$ They do, however, reflect the judgment of their nominators (usually upper administrators at their institutions) as to which of their faculty might be competitive for a national teaching award as well as the opinions of three panels of judges drawn annually from campuses, national associations, and foundations. As such, it is probably fair to say that they represent a collective sense within the larger higher education community about the pedagogical needs and possibilities of the time. Indeed, one of the main goals of the US Professors of the Year program was to focus public "attention on excellence in undergraduate teaching and provide models to which others can aspire."

Although the competition was not designed to provide a record of continuity and change in ideals for college teaching, the nominations do allow one to probe when and in what form various pedagogical innovations gained traction as award-worthy practice. I have addressed changes in pedagogy and educational leadership elsewhere (Huber, 2018). This essay focuses on how these award-winning faculty have participated in the teaching commons. How have the US Professors of the Year engaged departmental, institutional, and disciplinary colleagues in pedagogical and curricular change over the years, and how and when did systematic approaches to classroom inquiry and improvement made public emerge as exemplary practice ${ }^{4}$ Answers to these questions, I argue, speak also to understanding SoTL itself: Is it an activity primarily for the few, or is it an approach to college teaching fit for all?

\section{THE US PROFESSORS OF THE YEAR PROGRAM}

The US Professors of the Year award, led by the Council for the Advancement and Support of Education (CASE) in collaboration with the Carnegie Foundation for the Advancement of Teaching, served from 1981 to 2015 as the only continuous national award for college and university teaching in the United States. Open to faculty from all disciplines and types of institution, it named one national winner annually from 1981 to 1993, and then four each year from 1994 to 2015 representing community colleges, baccalaureate colleges, master's colleges and universities, and doctoral universities. ${ }^{5}$

Campuses were invited to nominate up to three of their best teachers each year for this award. From 1981 to 1993 nominations included a one-page, teaching-oriented CV, a list of courses taught in the current academic year, and six letters of support from students and colleagues. After 1994, nominees were also asked for a two-page statement about their special contributions as a teacher. Later candidates often expanded their teaching logs to include brief descriptions of the content and pedagogy for each 
course. In 1981, the program's inaugural year, there were 119 nominations; from the 1990s on, the number of nominations fluctuated from around 300 to 500 a year.

The program's selection criteria have always invited nominees and their sponsors to present a broad picture of the candidate as an educator. In its early phase (1981-1993), the program asked for evidence of "extraordinary effort as a teacher and/or scholar; extraordinary service to the institution and/or profession; a balance of achievement in teaching, scholarship, and service to the institution or profession; evidence of direct impact and involvement with students; evidence of distinction and achievement by former students;" and "the quality of nominations submitted by former students." After the program's redesign in 1994, the criteria were recast to focus more clearly on pedagogical creativity and educational leadership, with the wording remaining pretty much the same through the program's end in 2015:

- impact on and involvement with undergraduate students;

- scholarly approach to teaching and learning;

- contributions to undergraduate education in the institution, community, and profession; and

- $\quad$ support from colleagues and current and former undergraduate students. ${ }^{6}$

All judges used these criteria. CASE invited colleagues from the larger higher education community to serve in two preliminary rounds of judging that identified finalists based on numerical scoring. The finalists' materials were then sent to the Carnegie Foundation, which selected a new sixperson panel each year to choose the national winners. Comprising faculty (usually former national and/or state winners), administrators, and a student, this panel sought consensus through discussion. Prior to 1993, the single national winner was chosen from 24 to 30 finalists. After 1994, there were usually six finalists for each of the four awards.

The program's emphasis on contributions to undergraduate education in the institution, community, and profession invited nominees and recommenders to highlight a variety of engagements both on and beyond campus. And the official gloss on "scholarly approach to teaching" was broadly inclusive as well. When introduced in 1994, it included any or all of the following: "a step taken to evaluate and improve his or her teaching; innovative ways in which he or she evaluates student learning and provides feedback; a course he or she has created or a curriculum he or she has revised; examples of effective advising and mentoring techniques used by the professor; ways in which he or she shares innovative teaching techniques with other teachers; innovative ways he or she uses research and/or public service to illuminate teaching; or how he or she extends the learning process beyond the classroom." In 1998 the program added as another example, "stimulation of peer discussions of teaching and/or course design through publication, presentations, Web sites, etc.," and in 1999, the list expanded to include "any process taken to investigate" as well as "evaluate and improve, teaching." Although the brochure began defining "scholarly approach to teaching" in 2007 as "any process for investigating, evaluating, and improving teaching and learning, and sharing it with others," the gloss giving it a wide range of meaning remained available on the program website (www.usprofessorsoftheyear.org).

It is possible that the increase in the number of national winners engaged with the teaching commons and in SoTL simply track changes in the program's criteria from its pre- and post-1994 phases, or even changes in the small print later on. But it is more likely that changes in the winners' activities 
reflect real changes in the leading edge of college and university teaching, as interest in undergraduate research, service learning, new media, and SoTL caught on in higher education, providing new opportunities for faculty to develop and share pedagogical knowledge and expertise (Huber, 2018). Readers can find more information about the contest and the national winners on the US Professors of the Year website. Needless to say, these talented teachers have continued to develop new work, but the activities mentioned in this essay, as well as the quotations, come from their nomination and related award materials, and thus refer to the achievements for which they won the award.

\section{ENGAGING WITH COLLEAGUES ON EDUCATIONAL ISSUES}

Advocates of the scholarship of teaching and learning have long argued for the work's value beyond the sites in which such inquiry is initially conducted: "going public" with the results of classroom inquiry and improvement has been a defining feature of SoTL since its earliest days. ${ }^{7}$ Indeed, SoTL's most compelling promises have long included its capacity to make pedagogical knowledge "community property," put to an end to "pedagogical solitude," and raise the status of teaching in higher education (Shulman, 1993). In the process, SoTL practitioners have been helping to build a larger, more robust, and well-connected "teaching commons," in which pedagogical knowledge can "circulate, deepen through debate and critique, and inform the kinds of innovation so important to higher education today" (Huber \& Hutchings, 2005, p. 5).

Yet it is important to recall that the teaching commons existed prior to SoTL, and that every higher education institution and every field have long had a public sphere for pedagogical exchange and debate (Huber \& Morreale, 2002). These conversations were not always robust or well-respected by disciplinary peers, but there have been important exceptions and considerable change over time. In addition to the disciplines, a lively associational life also developed around specialized pedagogies and programs like undergraduate research, service learning, honors programs, and first-year programs. For innovative faculty members with strong pedagogical interests, these communities have long offered colleagues, ideas, venues for presentation and publication, and opportunities for leadership. For some participants, these communities and their forums also became fields for reform, as they worked to raise the level of scholarship and the quality of debate on teaching and learning in their different domains.

\section{On and beyond campus in the 1980s and 1990s}

It is not surprising to find that faculty members recognized as US Professors of the Year have been active contributors to these discussions from the competition's start. Most of the nine winners in the 1980s had made important contributions to academic programs on campus involving pedagogical conversation and collaboration with peers. For example, several were leaders in developing and coordinating interdisciplinary, team-taught courses. Among them Mary Eleanor Clark, a biologist, organized a course focused on ethical dilemmas in modern society, involving 15 faculty participants; and J. Dennis Huston, an English professor, directed a two-semester core course in the humanities, forming a strong intellectual community among the professors involved. Some of these Professors of the Year were also involved in committees to lead or reformulate general education on their campuses. Although few had taken on formal faculty development roles, Peter Beidler, another English professor, exchanged visits with a colleague as a means of improving teaching, and philosopher Rosemarie Tong organized an externally funded faculty seminar on integrating gender into the curriculum. 
Several of the winners from the 1980s had stepped onto a larger pedagogical stage. Beidler had designed English courses with real world assignments that garnered national coverage in the press, including a creative writing course in which students wrote for Redbook, with magazine staff involved in instruction and evaluation. Textbooks and materials also had a place in nominees' public repertoires: for example, Clark, the very first US Professor of the Year, had written a textbook with a distinctive emphasis on biology's contemporary relevance - then an innovative approach widely seen as a way to motivate a larger and more diverse set of college students to engage with science fields. Physicist Charles Pine had developed a curriculum for in-service training for teachers of mathematics based on his own experience with incoming students as well as on an analysis of statistics resulting from his state's basic skills placement test.

Contributions to the commons by the 28 US Professors of the Year in the 1990s broadened to include a considerably wider array of roles and forums. On campus, several had engaged colleagues with innovations in course design and pedagogy. J. W. Carmichael, Jr., a chemist at a historically black university redesigned his chemistry courses with an emphasis on small group work and peer tutoring and was serving as a consultant to other departments hoping to follow suit. Mark Taylor, then a humanities professor at a liberal arts college, was collaborating with faculty campus-wide on experimental courses using new technologies, including an interdisciplinary initiative in global studies with colleagues in chemistry and political science.

In this decade we begin to see pioneers in faculty development-Sally Wallace, a community college English professor, had designed a Writing Across the Curriculum program that brought English faculty together with faculty from other divisions; ${ }^{8}$ Christina Maslach, a professor of psychology, had developed a curriculum for $\mathrm{PhD}$ students in her department to learn to teach; Mary Sansalone, a professor of engineering, had designed a course to teach future professors in science and engineering how to teach; Marilyn Repsher, a math professor, was a campus leader for the integration of technology and collaborative learning into undergraduate courses. Repsher was also leading one of the on-campus groups engaged in a national initiative of the Carnegie Academy for the Scholarship of Teaching and Learning (CASTL) and would later become a CASTL scholar. ${ }^{9}$

Beyond campus, the US Professors of the Year in the 1990s were also quite active. Two had given workshops for educators at other institutions on the design of programs to promote minority student success in the sciences. Diane Keenan, a community college professor who taught economics in contexts like sports, music, and film through cooperative learning strategies, had trained "hundreds of full- and part-time community college faculty at national, regional and local workshops." Anne Hudson, a mathematics professor, was a regular presenter at her regional professional society conference, and Stephen Fisher, a political scientist, participated in service learning workshops both nationally and internationally. Many winners in the 1990s had written textbooks and developed curricula and materials for others to use-including some whose work was supported by external funding agencies.

Not surprisingly, given the rapid development of technology in the 1990s, there was strong interest in using new media for teaching and learning. For instance, Dean Zollman had created interactive physics lessons and designed software to allow students to analyze data collected from their own videotaped experiments. Indeed, he was involved in five recent and ongoing projects to develop materials for undergraduates - especially future elementary and high school teachers, and non-science students. In one, on quantum physics, "mathematical formalism is replaced with computer visualization and conceptual understanding." 
In addition to textbooks, materials, workshops, and conference presentations, over a dozen Professors of the Year in the 1990s reported publishing on educational issues in their field. Most prolific was Carmichael, the chemist, who had written 49 articles on science education, with a focus on making science accessible to minority students. Written in conjunction with other science faculty at his institution, these articles not only made public what they had learned about teaching these students, but also served as a way for colleagues in different fields to work together to help the students achieve their goals. Hong Gang Jin, whose research interests included "cognitive processing of languages," had written several articles on teaching Chinese; others included Harold R. Cohen, a biologist who published on experiential education; and David A. Berque, a computer scientist who wrote about the technology he developed to minimize the need for note-taking in the classroom. Sansalone, the engineering professor mentioned above, had published articles on her course on teaching science and engineering and on a course for freshmen based on the use of case studies for teaching structural engineering.

Interestingly, this decade also saw the first few nominations highlighting formal classroom inquiry and assessment for purposes of pedagogical and curricular improvement. Four winners systematically solicited student input to inform change. Sansalone discussed curriculum and course content changes with students as input to faculty meetings. Wallace, the community college English professor, asked students on the first day of class to identify characteristics of an ideal course, instructor, and student and then to review their lists at regular intervals and comment on how the class was going, how close they were to their ideals and what improvements might be made. Jin, the professor of Chinese mentioned above, had systematically studied the efficiency of various teaching methods on students with different levels of proficiency in Chinese.

Repsher, the fourth of these professors, designed one of her mathematics courses around pairs of students working on projects at a computer work station and remarked, "I do not have to wait for a test to find out what they know or what they fail to understand, for our on-going dialogue gives me immediate feedback on progress." She was also able to report from formal assessments that students in similarly designed courses "learn at least as much content as those in the traditional courses," while acknowledging that "attitudinal changes are harder to measure." Indeed, the latter had become the focus of her new research: "We have anecdotal evidence that students are happier with their instruction and more convinced that they can succeed in mathematics. Whether this, in the long run, produces more people doing more and better mathematics remains to be seen. My research will continue to investigate this."

\section{The growth of the commons and of SoTL in the 2000s and 2010s}

The 40 faculty members selected as US Professors of the Year in the first decade of the 2000s are emblematic of the growth of the teaching commons at this time, and its enrichment by classroom-based inquiry, program assessment, and discipline-based education research. With only four exceptions, the national winners of the 2000s highlighted contributions made to the teaching commons on campus and beyond. On campus, we find several who became involved in faculty development or whose pedagogical and curricula innovations became models that colleagues followed. Several, too, had written textbooks and developed materials - some of which became quite well known. Indeed, virtually all of the national winners in this decade had published and/or presented at other institutions and at conferences about teaching, learning, and other educational issues. About a quarter also mentioned their involvement in classroom-based inquiry and educationally relevant research. This proportion expanded in the 2010s, 
when at least three-quarters of the nationally recognized winners had engaged in the scholarship of teaching and learning or discipline-based education research.

Start on campus. In the 2000s, again are national winners who influenced the design of academic programs, like Robert Garvey, a physicist, who participated in the planning of a first-year program, insisting on a design that "would help [students] see that academic knowledge should not be separated from actual practices in the world." Dennis Jacobs, a chemist, developed and tested active learning pedagogy in a section of a large chemistry course, which became a model for other science departments. According to his chair, Jacobs's scholarship "affected the teaching paradigm in the whole department" and "changed the climate for assessment among the faculty." Another recommender noted how Jacobs guided other colleagues in research on teaching and learning, contributing to a knowledge-building enterprise across the entire campus.

Two of these professors had mentored their teaching assistants, while chemist Brian Coppola had developed programs for undergraduates, doctoral, and postdoctoral students to work on course design and classroom-based research. Formal programs for colleagues also received attention: Robert Bell, an English professor, had established his college's mentoring program for new faculty, while another English professor, Howard Tinberg, had taught a course on tutoring writing and was instrumental in creating his community college's center for teaching and learning.

In regard to textbooks and materials, national winners of the 2000 s included pioneers in the development of creative online resources. Among the most well known were historian Edward Ayers, physicist Carl Wieman, and anthropologist Michael Wesch. Ayers's "Valley of the Shadow Project," an archive of digitized records from two nearby communities, one in the north and one in the south, created with "two generations of student collaborators," enabled teachers and students anywhere to engage in authentic historical research on the civil war. Wieman's team's Physics Education Technology simulations, funded in part from Wieman's Nobel prize winnings, made "highly interactive visual models" in physics (and later other sciences as well freely available to students and teachers in high schools and colleges. Wesch's students' influential videos illustrating the possibilities of new media learning environments, went viral on YouTube: their original style of storytelling, one recommender explained, is "clarifying the nature and impact of developments that are transforming the internet and web from vehicles for discovery and retrieving documents to vehicles for facilitating human interaction."

For winners in the 2000's, textbooks and materials were no longer the main way in which US Professors of the Year went public with pedagogy. With interest growing in pedagogical expertise, most of these professors traveled to other campuses and to conferences, as well as publishing articles, chapters, and books. For many, these forums provided an opportunity to engage colleagues with special course or program designs: for example, community-based research for two-year college students (an anthropologist), laddered research teams for undergraduate laboratory research (a psychology professor), and experiential immersion learning (a geologist). ${ }^{10}$ Wieman was giving some 30 lectures a year on science education, using his prestige as a Nobel-prize winner to further faculty discussion about teaching and learning. And biologist Craig Nelson was publishing extensively on pedagogy that could foster students' capacities for deeper analysis and understanding: he also presented 291 workshops at national meetings and other institutions in the previous 10 years!

Many readers will recognize Wieman and Nelson as scholars who have made research on teaching and learning an important part of their own scholarship, while encouraging other faculty to engage in SoTL as well (see Nelson 2003; Wieman, 2007). Chemists Jacobs and Coppola based their 
classroom innovations on the science education literature and engaged in formal inquiry in their own courses and programs. Christopher Sorensen led a committee whose observations and research on new formats for teaching physics led to the implementation and improvement of a studio physics design.

This work was not limited to scientists. Howard Tinberg, the community college English professor, published over 30 reports, articles, and reviews on writing and pedagogy. In his acceptance speech for his national award, Tinberg said,

I have advocated the views for some time that teaching is a worthy subject for study and that the classroom can serve as a rich and varied site for research. My training as a writing teacher has made me comfortable with the view that learning depends, to some degree, on review, reflection, and revision. In other words, good things can happen to us as classroom instructors when we ask and answer questions such as, What happened in my classroom today? What did I expect to happen? What can I learn from the tension between what I expected and what I encountered on that day? How can I take what I've learned to enhance my teaching practice?

Tinberg considered himself a scholar of teaching and learning in faculty development as well as in his classroom. Indeed, his book Border Talk (1997) was an "ethnographic account of a three-week workshop on writing and thinking in the disciplines" that he "facilitated for faculty across the curriculum."

In the 2010s, the proportion of national winners who had been involved in SoTL (and other forms of education research) exploded - at least 15 of the 20 winners mentioned such work. Interestingly, this cadre included two psychologists who made strong efforts to bring their disciplinary scholarship to bear on issues of teaching and learning. Christy Price drew on her research on millennial learners to help design her college's first year experience program, and to inform her own teaching, redesigning all her courses to "include even more active learning and frequent formative assessment." Stephen Chew brought lessons to colleagues from his research on undergraduates' misconceptions and teachers' use of examples. "Most teachers," Chew wrote,

mistakenly believe learning comes from active engagement and student struggle. Engagement alone, however, is not sufficient for learning, and although learning is hard work for students, not all hard work leads to learning. I give teachers the knowledge to design presentations, assignments and activities that optimize student learning.

Among the winners of the 2010s are several who shifted their research focus to pedagogical themes. Biologist Teresa Balser, for example, wrote, "In recent years I have made a transition from scholarly teaching to the scholarship of teaching. In my quest to better understand what makes learning happen I have begun to learn the new (for me) field of discipline-based education research." One of three co-founders of a discipline-based education research group funded by a pilot grant from the National Science Foundation, she already had eight volunteered posters, five published education articles, and several others in preparation. At the time Balser was also "collecting data about the way that majors and non-majors in the sciences ask questions," and "studying the development of student identity as a 'scientist." At least ten other national winners from the 2010s had made SoTL or discipline-based 
education research an important (and for some, major) focus for research. These included a mathematician, geologist, chemist, two English professors, two engineers, and three physicists.

Yet it is important to note that many nominees in the 2010s also presented SoTL as a regular part of teaching. John Wadach, a professor who transformed his college's traditional lab and lecture curriculum to one based on a "design and build" pedagogy, wrote, "I've grown to understand that excellence in teaching involves constantly re-evaluating what I'm teaching and how I'm teaching it, while continually striving for the most creative and effective methods to maximize student learning and student success." Stephanie Alvarez, a professor of Spanish and Mexican-American studies, wrote, "I continually assess the needs of the students and adapt my teaching and content to maximize student achievement while also expanding the base knowledge in Latina/o Studies." Brian Alegant, a music professor, wrote, "I have spent my entire teaching career experimenting with, reflecting upon, and redesigning my courses in an effort to promote deeper learning and personal growth. Indeed, I've never taught the same way twice." Citing inspiration by the writings of authors like Ken Bain, Dee Fink, Peter Elbow, and Wilbert McKeachie, Alegant developed a nontraditional mode of organizing his music theory course that brings the field closer to performance than usual.

Whether done as research or teaching (or both), however, these same professors shared their work with colleagues. Wadach gave presentations on implementing a design-build curriculum to disciplinary association audiences. Alvarez said that four of her recent publications on teaching MexicanAmerican studies became popular in a short period of time. And Alegant's workshops and journal articles on teaching music theory had, according to one colleague, influenced the pedagogy of 10 to 15 percent of their professional society's 1,150 members.

\section{SOTL AND THE TEACHING COMMONS}

Citizenship in the teaching commons has always been open to contributions based on a wide range of experience and inquiry. This fact is well illustrated by the activities of the US Professors of the Year. From the program's beginning in 1981 to its end in 2015, innovative and thoughtful teachers have found many ways to join the conversation about teaching and learning in higher education and engage colleagues in pedagogical and curricular exchange. And there was a lot to talk about and do in this era of rapid change. On campus, there were programs to design or update, new technologies and new media to develop for pedagogical purposes, new knowledge about learning to apply, and new strategies to explore for active learning, service learning, study-abroad, undergraduate research, and professional development for teaching assistants and colleagues.

Those who wished to contribute to the larger commons could do so by writing textbooks, creating materials, presenting and publishing their work, or engaging in multi-campus pedagogical projects. As time went on, the US Professors of the Year's contributions were increasingly informed by SoTL, discipline-based education research, or other kinds of educationally relevant research. This has been the promise of SoTL all along - to enlarge and enrich the discourse communities where exchange about teaching and learning takes place, and to help raise the effectiveness (and status) of college and university teaching by developing its knowledge base.

This ambition raises the difficult question of who SoTL is for. The commons can be understood as the property of all its citizens - including those who occasionally seek ideas or resources or collaborators in a larger sphere than their more intimate circles of colleagues (Roxå \& Mårtensson, 2009). "Scholarly teaching" is the term often used to refer to the use of these resources for the design 
and improvement of courses, programs, and other learning environments (Hutchings \& Shulman, 1999). Yet the definition of "scholarly approach to teaching" in the US Professors of the Year competition also includes "processes for investigating, evaluating, and improving teaching and learning, and sharing it with others," the territory usually referred to by SoTL itself. Not surprisingly, a greater proportion of the national award winners were engaged in this work in the 2000s and especially the 2010s, with quite a few making it their principal form of scholarship.

So, is SoTL just for the pedagogical elite? From one perspective, the answer is "yes." SoTL can be seen as a relatively rigorous approach to pedagogical understanding and improvement-not an activity that even its more committed practitioners engage in all the time. From another perspective, however, the answer is "no." SoTL can also be seen as an approach to teaching and learning that can be practiced in less elaborate ways, and is thus an activity that can become part and parcel of what it means for anyone to be a teacher in higher education.

The dossiers of the US Professors of the Year suggest that the broader view is a real possibility. Consider the following activities, only slightly generalized from the wording in the nominations: relying on regular student input to improve one's courses; learning to see one's field from an outsider's perspective and then to reconceive one's teaching with an eye to barriers students face in understanding the subject; formulating teaching moves that take account of research on learning; trying to align learning objectives, pedagogical approach, and assessment strategies in order to systematically document connections between teaching practice and student learning; or engaging in reflective practice by framing questions about one's teaching, seeking possible answers, and enacting in the classroom what one has learned. Put inquiry and improvement activities like these together with citizenship in the commons-drawing on and contributing back to our collective knowledge about teaching and learning - and one is well on the way to SoTL for all.

\section{CONCLUSION}

The US Professors of the Year competition provides a unique window onto changes in higher education's teaching culture from 1981 to 2015. Over that time, we can see changes in the ways that national winners have engaged with colleagues about issues in teaching and learning, and a steady increase in the proportion of national winners who have engaged in SoTL and related kinds of pedagogical research. In the 1980s and 1990s, the primary way of "going public" with teaching beyond campus was through writing textbooks and materials, while in the 2000s and 2010s presentations and publications took the lead. During this same period, engagement in SoTL rose from nil in the 1980s to around 10 percent in the 1990s, 25 percent in the 2000s, and 75 percent in the 2010s. Looked at another way, the proportion of national winners contributing to the teaching commons beyond campus rose from just under a half in the 1980 s to 80 percent in the 1990s, to nearly 90 percent in the 2000s, and 100 percent in the 2010s. ${ }^{11}$

What does this mean? That campuses were following the evolving rules of the competition and nominating the "thin slice" of faculty best suited to win? That "going public" beyond campus was in fact becoming a more valued part of college and university teaching? That there were more opportunities for people to speak, publish, and do research on teaching and learning as time went on? All of these are possible, and open to discussion. However, I believe that the historical arc marked by the national winners of the US Professors of the Year from 1981 to 2015 bends toward the emergence of a new view of teaching in higher education — one that has been characterized by Carl Wieman, a winner in 2004, as 
"an activity that involves true expertise that comes from knowledge and careful practice, rather than merely a matter of individual opinion and expression" (2017, p. 123).

This is not to say that expertise is the only ingredient in effective, much less extraordinary, achievement in teaching. Caring and character also matter, of course, and these are evident as well in the nomination materials of the US Professors of the Year. Less evident, but no less important, are the systems that support pedagogical creativity and citizenship in the teaching commons. Most nominees to this competition have been the beneficiaries of tenure-track positions in colleges and universities that have supported and celebrated their efforts to explore new ideas for teaching and learning and participate in the growing number of venues in which such ideas are shared.

The US Professors of the Year have always provided a vision of the possible for teachers in higher education, embodying emergent trends in pedagogy, educational leadership, and citizenship in the commons. Some of the achievements represented by national winners in earlier years have already entered, or approached, the mainstream of college pedagogy - a focus on a subject's real-world relevance, interdisciplinary and integrative learning, and "high impact" practices, like undergraduate research, service learning, and study abroad (Kuh, 2008). Yet if this new view of teaching and pedagogical improvement based on knowledge, inquiry, and practice is to spread far beyond the prizewinners and their immediate communities, then more colleges and universities will need to provide opportunities to all their faculty to develop expertise about teaching and learning and share it with colleagues both near and far away.

\section{ACKNOWLEDGMENTS}

Many thanks to the national winners of the US Professors of the Year program. It has been a privilege and a pleasure to read and discuss their nominations with the final judging panels in this competition since 1991. I am grateful to the Carnegie Foundation for the Advancement of Teaching for the opportunity to work on this program over so many years, and to three anonymous reviewers for the TLI for thoughtful comments on this essay.

Mary Taylor Huber is Senior Scholar Emerita at the Carnegie Foundation for the Advancement of Teaching and Senior Scholar with the Bay View Alliance. From 1991 to 2015 she convened the final judging panel for the US Professors of the Year competition.

\section{NOTES}

1. The phrase "extraordinary dedication to undergraduate teaching" was emblazoned on the program's logo from the logo's introduction in 1994 until the program's conclusion in 2015. The word "faculty" refers here to individual teachers in higher education institutions. It is used interchangeably with terms like "faculty member," "teacher," "instructor," and "professor."

2. The competition was open to faculty members of any academic rank, full- or part-time, but colleges and universities usually nominated full-time tenure-track or tenured faculty for the award.

3. This phrase is from the call for nominations that can be found on the program website.

4. This definition is based on McKinney (2006): "the scholarship of teaching and learning" she writes, "involves systematic study of teaching and/or learning and the public sharing and review of such work through presentations, performance, or publications" (p. 39). In its classic form, the work has four defining features (Huber \& Hutchings, 2005, pp. 20-29). The work takes place in the classroom (or other learning environment, like lab, field site, or community setting) where faculty membersalone or with a colleague and/or students as co-inquirers-ask questions about their students' learning, gather and explore evidence to answer or shed light on those questions, try out new pedagogical strategies and refine insights (an iterative process), and make public what they have 
found out. SoTL is often distinguished from discipline-based education research (National Research Council, 2012) and other kinds of research in the learning sciences (e.g., Bransford, Brown, \& Cocking, 1999) as a highly contextualized, local, or "situated" mode of inquiry (Shulman, 2013; Chick \& Poole, 2018), although SoTL at times shades into these other modes of education-related research.

5. From 1981 to 1993 , eligibility was restricted to faculty teaching at CASE member-institutions. In 1994, eligibility was expanded to faculty at all accredited degree-granting institutions of higher education. The program also began recognizing state winners in 1985, selecting one from each of the 50 states, the District of Columbia, and the US territories, when there were enough entries of sufficient quality. According to the program website, more than 1,200 faculty were recognized as winners at the national or state level.

6. The first iteration of the second criterion in 1994 was "teaching informed by scholarship." This was changed in 1995 to "scholarly approach to teaching" to clarify the program's interest in teaching informed by pedagogically relevant knowledge and inquiry. Clearly these criteria are SoTL-friendly. This is no surprise. One of the program sponsors, the Carnegie Foundation for the Advancement of Teaching - long an advocate for SoTL-was involved in framing the criteria for selection, and the committee that met to restructure the award in the 1993, also included a representative from the American Association for Higher Education (AAHE). At that time, Scholarship Reconsidered: Priorities of the Professoriate, by Carnegie's then-president Ernest Boyer, published in 1990, was stirring a lively debate with its call for a broader understanding of the intellectual work of faculty, including the "scholarship of teaching," a term introduced in that report. By 1993, too, AAHE was providing a special annual forum for the higher education community to develop these new ideas about faculty roles and rewards.

7. Although Boyer's discussion of the "scholarship of teaching" in Scholarship Reconsidered (1990) did not discuss sharing pedagogical insights with colleagues, the Carnegie Foundation's follow-up report, Scholarship Assessed (Glassick, Huber, \& Maeroff, 1997) included "effective presentation" and "reflective critique" as two of six criteria for the evaluation of scholarship of any kind. For Hutchings and Shulman, the scholarship of teaching involved "question-asking, inquiry, and investigation, particularly around issues of student learning" and "the three additional central features of "being public ('community property'), open to critique and evaluation, and in a form others can build upon" (1999, p. 13).

8. This program was established in the early 19805 but is an accomplishment of a professor who was nominated and won the US Professor of the Year award in the 1990s. Throughout this essay, dates refer not the time of any individual activity but to the decade in which a candidate's career accomplishments were judged to be worthy of this national award.

9. CASTL, a national (and at later dates, international) program, ran from 1998 to 2009. It included a national fellowship program for CASTL Scholars; a campus program; and a program for disciplinary associations (see Hutchings, Huber, \& Ciccone, 2011, Appendix B). Over the years, nine national winners and at least three state winners in the US Professors of the Year competition either later became or were earlier selected as CASTL Scholars in the national fellowship program.

10. Experiential immersion learning refers to a curriculum that this professor helped design in which students take a single course for 18 instructional days at a time, providing opportunities for faculty and students to engage in intensive field experiences.

11. It is fair to note, however, that one of the main limitations of the nomination materials used in this study concerns how comprehensive a record they provide. It was certainly possible (especially after the program's redesign in 1994) to pack a great deal of information into nominees' teaching CVs, course logs, personal statements, and recommendations, but these packets can hardly present a complete picture of the candidates' teaching lives. What have nominees done that are not represented in these materials? This question is especially pertinent to the records of the winners from 1981 to 1993, who were not asked to submit a personal statement. 


\section{REFERENCES}

Boyer, E. L. (1990). Scholarship reconsidered: Priorities of the professoriate. Princeton, NJ: The Carnegie Foundation for the Advancement of Teaching.

Bransford, J. D., Brown, A. L., \& Cocking, R. S. (Eds.). (1999). How people learn: Brain, mind, experience, and school. Committee on Developments in the Science of Learning. Commission on Behavioral and Social Sciences and Education, National Research Council. Washington, DC: National Academy Press.

Chick, N. L., \& Poole, G. (2018). In defense of microscopes. Teaching \& Learning Inquiry, 6(1). https://doi.org/10.20343/teachlearninqu.6.1.1

Glassick, C. E., Huber, M. T., \& Maeroff, G. I. (1997). Scholarship assessed: Evaluating the professoriate. San Francisco, CA: Jossey-Bass.

Huber, M. T. (2004). Balancing acts: The scholarship of teaching and learning in academic careers. Washington, DC: American Association for Higher Education.

Huber, M. T. (2018). The leading edge of pedagogical innovation: A portrait of national winners of the US Professors of the Year competition, 1981-2015. Change: The Magazine of Higher Learning, 50(3/4), 7983. https://doi.org/10.1080/00091383.2018.1509611

Huber, M. T., \& Morreale, S. P. (2002). Situating the scholarship of teaching and learning: A cross-disciplinary conversation. In M. T. Huber \& S. P. Morreale (Eds.), Disciplinary styles in the scholarship of teaching and learning: Exploring common ground (pp. 1-24). Washington, DC: American Association for Higher Education.

Huber, M. T., \& Hutchings, P. (2005). The advancement of learning: Building the teaching commons. San Francisco, CA: Jossey-Bass.

Hutchings, P., Huber, M. T., \& Ciccone, A. (2011). The scholarship of teaching reconsidered: Institutional integration and impact. San Francisco, CA: Jossey-Bass.

Hutchings, P. \& Shulman, L.S. (1999). The scholarship of teaching: New elaborations, new developments. Change: The Magazine of Higher Education, 31(5), 10-15. https://doi.org/10.1080/00091389909604218

Kuh, G. D. (2008). High-impact educational practices: What they are, who has access to them and why they matter. Washington, DC: Association of American Colleges and Universities.

McKinney, K. (2006). Attitudinal and structural factors contributing to challenges in the work of the scholarship of teaching and learning. New Directions for Institutional Research, 129, 37-50. https://doi.org/10.1002/ir.170

National Research Council. (2012). Discipline-based education research: Understanding and improving learning in undergraduate science and engineering. S. R. Singer, N. R. Nielsen, and H. A. Schweingruber (Eds.), Committee on the Status, Contributions, and Future Directions of Discipline-Based Education Research. Board on Science Education, Division of Behavioral and Social Sciences and Education. Washington, DC: National Academies Press.

Nelson, C.E. (2003). Doing it: Selected examples of several of the different genres of the scholarship of teaching and learning. Journal on Excellence in College Teaching, 14 (2/3), 85-94.

Roxå, T. \& Mårtensson, K. (2009). Significant conversations and significant networks-exploring the backstage of the teaching arena. Studies in Higher Education, 34(5), 547-539. https://doi.org/10.1080/03075070802597200

Shulman, L. S. (1993). Teaching as community property. Putting an end to pedagogical solitude. Change: The Magazine of Higher Learning, 25(6), 1-22.https://doi.org/10.1080/00091383.1993.9938465

Shulman, L. S. (2013, October). Situated studies of teaching and learning: The new mainstream. Plenary address at the annual conference of the International Society for the Scholarship of Teaching and Learning. Retrieved from https://www.youtube.com/watch?v=bhvwLW-5zMM

Tinberg, H. M. (1997). Border talk: Writing and knowing in the two-year college. Urbana, IL: National Council of Teachers of English.

Wieman, C. (2007). Why not try a scientific approach to science education? Change: The Magazine of Higher Learning, 39(5), 9-15.

Wieman, C. (2017). Improving how universities teach science: Lessons from the science education initiative. Cambridge, MA: Harvard University Press. 


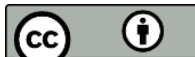

Copyright for the content of articles published in Teaching \& Learning Inquiry resides with the authors, and copyright for the publication layout resides with the journal. These copyright holders have agreed that this article should be available on open access under a Creative Commons Attribution License 4.0 International (https://creativecommons.org/licenses/by/4.0). The only constraint on reproduction and distribution, and the only role for copyright in this domain, should be to give authors control over the integrity of their work and the right to be properly acknowledged and cited, and to cite Teaching \& Learning Inquiry as the original place of publication. Readers are free to share these materials-as long as appropriate credit is given, a link to the license is provided, and any changes are indicated. 